\title{
Upaya Meningkatkan Minat Belajar Siswa Melalui Penerapan Model Teams Games Tournament (TGT) dengan Reward and Punisment pada Pembelajaran Sosiologi di SMAN 3 Padang
}

\author{
Wahyu Ramadhani Putri ${ }^{1}$, Junaidi Junaidi ${ }^{2}$ \\ ${ }^{1,2}$ Universitas Negeri Padang \\ Email: wahyuramadhaniputri@gmail.com, junaidiunp@fis.unp.ac.id
}

\begin{abstract}
Abstrak
Penelitian ini dilatar belakangi oleh rendahnya tingkat minat siswa kelas XI IPS 2 dalam pembelajaran sosiologi, untuk mengatasi masalah, perlu dilakukan tindakan dalam proses pembelajaran untuk meningkatkan minat siswa tersebut. Untuk mengatasi permasalahan ini peneliti menerapkan model Teams Games Tournament dengan Reward and Punishment. Penelitian ini bertujuan untuk mengetahui adanya peningkatan minat belajar siswa pada mata pelajaran sosiologi melalui penerapan model kooperatif Teams Games Tournament dengan Reward and Punishment di SMAN 3 Padang. Jenis penelitian ini adalah Penelitian Tindakan Kelas. Penelitian ini dilaksanakan sebanyak 2 siklus, dalam setiap siklus terdapat 2 kali pertemuan dan setiap siklus terdapat 4 jenis kegiatan yaitu perencanaan, pelaksanaan, pengamatan dan refleksi. Subjek penelitian ini adalah siswa kelas XI IPS 2 SMAN 3 Padang yang jumlah siswanya sebanyak 35 orang. Instrument penelitian ini menggunakan angket yang berisi indikator minat belajar siswa. Target tingkat capaian dalam penelitian ini adalah kategori baik pada interval $60 \%$ ketas. Hasil penelitian ini diolah dengan rumus $\mathrm{P}=(\mathrm{F} / \mathrm{N}) \mathrm{X} 100 \%$. Hasil penelitian ini menunjukkan adanya peningkatan minat belajar dengan penerapan model Teams Games Tournament dengan Reward and Punishment. Dapat dilihat pada pertemuan siklus I rata-rata skor minat belajar siswa yaitu sebesar $75,6 \%$ dan pada siklus II skor minat siswa yaitu sebesar $94,6 \%$.
\end{abstract}

Kata kunci: Minat, Reward and Punishment, Teams Games Tournament

\section{Abstract}

This research is motivated by the low-level of interest of students in class XI IPS 2 in learning sociology, to overcome the problem, it is necessary to take action in the learning process to increase the interest of these students. To overcome this problem researchers applied the Teams Games Tournament model with Reward and Punishment. This research aims to find an increase in student interest in sociology through the application of the Teams Games Tournament cooperative model with Reward and Punishment at SMAN 3 Padang. This type of research is Classroom Action Research. This research conducted in 2 cycles, in each cycle there were 2 meetings and each cycle there were 4 types of activities namely planning, implementation, observation and reflection. The subjects of this resarch were students of class XI IPS 2 of SMAN 3 Padang, with 35 students. This research instrument uses a questionnaire that contains indicators of student interest in learning. The target level of achievement in this study is a good category at $60 \%$ interval. The results of this research were processed with the formula $P=(F / N) \times 100 \%$. The results of this research show an increase in interest in learning by applying the Teams Games Tournament model with Reward and Punishment. Can be seen in the first cycle meeting the average score of students 'interest in learning is equal to $75.6 \%$ and in cycle II the score of students' interest is in the amount of $94.6 \%$.

Keywords: Interests, Reward and Punishment, Teams Games Tournament

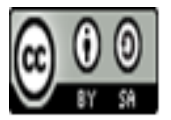

\begin{tabular}{|l|l|l|}
\hline Received: April 26, 2020 & Revised: May 12, 2020 & Accepted: May 13, 2020
\end{tabular}




\section{Pendahuluan}

Pembelajaran adalah sebuah bentuk kegiatan para pengajar yang tersusun untuk membuat belajar secara aktif dan lebih menekankan pada sumber belajar itu sendiri (Sagala, 2011). Pembelajaran adalah salah satu bentuk upaya membelajarkan peserta didik untuk belajar. Kegiatan semacam ini mengakibatkan peserta didik mempelajari sesuatu dengan cara yang lebih efesien dan efektif (Muhaimin, 1996). Pembelajaran adalah salah satu bentuk usaha mengorganisasikan suatu lingkungan dan menghasilkan kondisi belajar untuk pesera didik (Hamalik, 2001). Pembelajaran di dalam kelas merupakan salah satu bagian sangat penting dalam proses pendidikan, jika pelaksanaan suatu pembelajaran itu di kelas yang bermutu maka akan menghasilkan output yang berkualitas juga tentunya (Tyasning, Haryono, \& Nurhayati, 2012). Salah satu kecermatan guru untuk menata aktivitas pembelajaran sangat menentukan kualitas hasil pembelajaran. Pada kenyataannya yang ada pada saat ini menunjukkan adanya kebanyakan guru masih menerapkan model pembelajaran dengan metode lama seperti guru sebagai pusat pembelajaran dengan ceramah. Hal ini akan bisa membuat peserta didik dalam proses pembelajaran bukan hanya memberikan segala informasi dan keterampilan kepada siswa, melainkan hanya menekankan pada proses yang melibatkan peserta didik aktif dalam mengembangkan kemampuan yang dimilki peserta didik (Suri, 2018). Salah satu yang menunjang proses pembelajaran peserta didik yaitu mata pelajaran sosiologi.

Sosiologi adalah ilmu yang membahas tentang pola-pola masyarakat dan akibat yang ditimbulkan yaitu nilai dan norma. Sosiologi adalah mata pelajaran di tingkat SMA/MA dimana mata pelajaran ini membahas tentang fakta-fakta dalam masyarakat. Tujuan dari mata pelajaran ini supaya siswa bisa menjadi warga yang memilki rasa peduli dan sosialitas yang tinggi di lingkungan sekitar dan bisa mengatasi masalah sosial dilingkungan sekitar ( Susanti \& Junaidi, 2020). Pembelajaran Sosiologi di SMA bukan hanya sekedar memahami teori, konsep dan fakta melainkan juga diharapkan bisa mengembangkan kemampuan potensi kerjasama yaitu peserta didik saling bersinergi, beradaptasi dan bertanggungjawab, bekerja secara produkti, empati dan menghargai pendapat dan pemikiran yang berbeda (Vermana \& Sylvia, 2019). Dalam belajar sosiologi sangat penting suatu minat belajar, karena minatlah yang bisa menunjang efektif dan efesiennya proses pembelajaran. Rasa tertarik pada suatu pembelajaran dimaksudkan jika individu itu minat pada suatu kegiatan tersebut sehingga individu itu akan menunjukkan dengan rasa rajin dan rasa ingin tahunya saat belajar pada mata pelajaran tersebut (Mayani \& Junaidi, 2020). Menurut Budiwibowo (2016) dalam (Rosalina, 2020) di dalam kegiatan belajar mengajar sangat perlu sekali adanya suatu perhatian supaya yang dipelajari dapat dimengerti oleh peserta didik. Supaya minat belajar siswa meningkat, kegiatan belajar bisa dilakukan dalam bentuk kegiatan, seperti belajar sambil berbuat, maka akan ada yang dialami saat ada di lingkungan tersebut secara sendiri maupun bersama. Minat yaitu adanya rasa menyukai dan tertarik dan juga adanya terkenang kegiatan tersebut (Slameto, 2010). Minat belajar yaitu menyukai dan senang, tertarik kepada suatu pelajaran dan tidak ada yang memaksa Minat adalah rasa menyukai kepada suatu hal ataupun kegiatan yang timbul dari internal siswa tersebut. Minat belajar sangatlah penting bagi setiap peserta didik. Dengan adanya minat maka proses pembelajaran akan lebih efesien, dan lebih berkontribusi saat belajar, akan bisa mengingat pelajaran dan merasa tidak jenuh saat proses pembelajaran tersebut. Tapi kenyataannya minat belajar siswa kelas XI IPS 2 SMAN 3 Padang masih terbilang rendah. Rendahnya minat belajar siswa dapat dilihat juga dari proses belajar mengajar di kelas dilaksanakan, siswa terlihat sangat malas, terlihat jenuh, dan tidak bergairah, siswa pun kelihatan tidak gembira atau merasa terpaksa melakukan proses belajar yang dimana terlihat dari kurang maksimalnya siswa ketika mengerjakan tugas yang diberikan guru. 
Wahyu Ramadhani Putri, Junaidi Junaidi Upaya Meningkatkan Minat Belajar Siswa Melalui Penerapan Model Teams Games Tournament (TGT) dengan Reward and Punisment pada Pembelajaran Sosiologi di SMAN 3 Padang

Data tersebut dapat dilihat dari tabel berikut ini:

Tabel 1. Studi Pendahuluan Minat Belajar Siswa Kelas XI IPS 2 pada Semester Juli-Desember 2019

\begin{tabular}{llll}
\hline No & Indikator Minat Belajar & $\begin{array}{l}\text { Jumlah } \\
\mathbf{N = 3 5}\end{array}$ & $\begin{array}{l}\text { Persentase } \\
\mathbf{P = F} / \mathbf{N} \text { X 100\% }\end{array}$ \\
\hline 1 & $\begin{array}{l}\text { Kecendrungan menetap } \\
\text { memperhatikan }\end{array}$ & 16 & $46 \%$ \\
\hline 2 & Rasa suka dan senang & 15 & $43 \%$ \\
\hline 3 & Antusias & 9 & $26 \%$ \\
\hline 4 & Rasa ingin tahu & 13 & $37 \%$ \\
\hline 5 & Kepuasan & 7 & $20 \%$ \\
\hline & Rata-rata & 12 & $34,4 \%$ \\
\hline
\end{tabular}

Berdasarkan hasil penyebaran angket tersebut dapat disimpulkan bahwa rata-rata minat belajar siswa di kelas XI IPS 2 SMAN 3 Padang ini hanya sebesar 34,4\%. Artinya persentase jauh dari kata baik. Pada indikator kecendrungan menetap untuk memperhatikan proses pembelajaran hanya $46 \%$, indikator menyukai proses pembelajaran rasa suka dan senang sebesar $43 \%$, indikator antusias terhadap proses pembelajaran sebesar $26 \%$, indikator rasa ingin tahu terhadap topik yang dipelajari sebesar $37 \%$ dan indikator kepuasan terhadap pencapaian belajar sebesar $20 \%$. Data ini memperlihatkan permasalahan siswa dalam minat belajar siswa pada proses pembelajaran sosiologi. Kualitas pelaksanaan pembelajaran di sekolah adalah pondasi awal keberhasilan proses pendidikan (Sylvia, Anwar, \& Khairani, 2019), untuk mengatasi permasalahan tersebut peneliti menerapkan penerapan model pembelajaran kooperatif Teams Games Tournament dengan reward and punishment pada kelas XI IPS 2.

Pembelajaran kooperatif yaitu suatu bentuk model belajar yang peserta didik belajar dan mengerjakan dalam bentuk kelompok kecil yang anggotanya 4-6 peserta didik dengan struktur kelompok yang bercampur (Robert E. Slavin, 2010). Pembelajaran kooperatif adalah rangkaian kegiatan pembelajaran yang dilaksanakan peserta didik di dalam kelompok untuk menunjang tujuan yang telah ditentukan (Abdul, 2015). Salah satu model pembelajaran kooperatif yaitu model pembelajaran Teams Games Tournament (Tyasning et al., 2012). TGT adalah permainan dan bertanding yang bertim dikembangkan oleh David Vries dan Keath Edward pada tahun 1995. (Istarani, 2012). Permainan dapat merangsang minat belajar siswa dalam kegiatan belajar sehingga peserta didik menjadi terdorong dan memilki minat untuk proses pembelajaran. Pada model ini peserta didik memainkan permainan dengan anggota-anggota tim lain untuk memperoleh tambahan point untuk skor tim mereka (Istarani, 2012). Pemberian reward akan diberikan kepada kelompok-kelompok yang lebih menonjol dari kelompok lain. Artinya reward ini dibuat untuk menjadi suatu penghargaan agar siswa berminat lagi pada pelajarn sosiologi di kelas. Dan punishment ini adalah bentuk hukuman yang baik untuk memancing minat belajar para siswa.

\section{Metode Penelitian}

Penelitian ini adalah Penelitian Tindakan Kelas, yaitu sebagai pencermatan kepada aktivitas seperti adanya tindakan, secara disengaja munculnya dan aktivitasnya dilaksanakan di suatu ruangan secara berkelompok (Arikunto, 2008). PTK adalah bagian dari penelitian tindakan (action research) (Jefri \& Junaidi, 2019). Penelitian Tindakan Kelas (PTK) tujuannya bukan sekedar untuk menunjang hasil belajar siswa saja, namun bisa juga untuk meningkatkan skill pengajar dalam 
proses pembelajaran, dengan kata lain PTK ini tidak hanya mencari penyebab dari masalah tetapi juga memberikan pemecahan masalah berupa tindakan-tindakan untuk mengatasinya (Nurlizawati, 2019). Penelitian ini dilakukan pada kelas XI IPS 2 SMAN 3 Padang, dengan menggunakan model siklus yang terdiri dari 4 pertemuan pada tahun ajaran Januari-Juni 2020, pada materi konflik sosial. Instrument yang digunakan pada pengambilan data yaitu menggunakan angket dengan komponen minat belajar siswa dan dokumentasi sebagai bukti kegiatan proses pembelajaran sosiologi menggunakan model Teams Games Tournament. Penelitian ini menggunakan indikator keberhasilan yaitu 70\%-80\% dikatakan baik dan 80\%-100\% dikatakan sangat baik, dari hasil observasi komponen minat belajar dari keseluruhan siswa. Pengolahan data $\mathrm{PTK}$ ini digunakan rating classes dengan rumus $\mathrm{P}=\mathrm{F} / \mathrm{N} X 100 \%$. (Trianto, 2010).

\section{Hasil dan Pembahasan}

Penelitian ini dilakukan di Kelas XI IPS 2 SMAN 3 Padang, dengan langkah awal pertemuan pra tindakan, selanjutnya dilakukan pertemuan Siklus I dan Siklus II (sebanyak empat pertemuan). Pada setiap siklus peneliti melaksanakan model pembelajaraan kooperatif Teams Games Tournament. Berikut gambaran dari hasil pelaksanaan penelitian yang telah dilakukan.

\section{Pra Tindakan}

Pertemuan pra tindakan ini dilakukan sebelum dilaksanakan penelitian. Pertemuan ini digunakan untuk mengamati seberapa minat belajar siswa di kelas XI IPS 2 SMAN 3 Padang. Setelah dilakukan pertemuan ini peneliti beserta kolaborator menyebarkan angket kepada peserta didik. Minat belajar peserta didik dapat dilihat dari hasil rata-rata pada indikator yang diamati. Di pertemuan pra tindakan ini rata-rata minat belajar siswa yaitu $34,4 \%$ atau dalam kategori kurang. Berikut ini hasil dari pra tindakan:

Tabel 2. Hasil Minat Belajar Siswa Pada Pertemuan Pra Tindakan

\begin{tabular}{llll}
\hline No & Indikator Minat Belajar & $\begin{array}{l}\text { Jumlah } \\
\mathbf{N = 3 5}\end{array}$ & $\begin{array}{l}\text { Persentase } \\
\mathbf{P = F} / \mathbf{N} \mathbf{X} \mathbf{1 0 0} \%\end{array}$ \\
\hline 1 & $\begin{array}{l}\text { Kecendrungan menetap } \\
\text { memperhatikan }\end{array}$ & 16 & $46 \%$ \\
\hline 2 & Rasa suka dan senang & 15 & $43 \%$ \\
\hline 3 & Antusias & 9 & $26 \%$ \\
\hline 4 & Rasa ingin tahu & 13 & $37 \%$ \\
\hline 5 & Kepuasan & 7 & $20 \%$ \\
\hline & Rata-rata & 12 & $34,4 \%$ \\
\hline
\end{tabular}

Berdasarkan hasil dari data disimpulkan bahwa minat belajar siswa kelas XI IPS 2 SMAN 3 Padang ini dikategorikan rendah atau kurang. Sehingga peneliti mencari jalan keluar untuk bisa meningkatkan minat belajar siswa di kelas ini dengan cara melakukan penelitian dan proses belajar mengajar digunakan model pembelajararan kooperatif Teams Games Tournament dengan Reward and Punishment.

\section{Siklus I}

Pada siklus I ini dibantu oleh kolaborator untuk melaksanakan penyebaran angket minat belajar untuk para siswa. Minat belajar siswa dilihat dari rata-rata masing-masing indikator minat belajar yang diamati. Pada siklus I ini rata-rata minat belajar siswa yaitu 75,6\% atau masih di interval baik. Berikut ini data hasil Siklus I: 
Wahyu Ramadhani Putri, Junaidi Junaidi Upaya Meningkatkan Minat Belajar Siswa Melalui Penerapan Model Teams Games Tournament (TGT) dengan Reward and Punisment pada Pembelajaran Sosiologi di SMAN 3 Padang

Tabel 3. Hasil Minat Belajar Siswa Pada Pertemuan Siklus I

\begin{tabular}{llll}
\hline No & Indikator Minat Belajar & $\begin{array}{l}\text { Jumlah } \\
\mathbf{N = 3 5}\end{array}$ & $\begin{array}{l}\text { Persentase } \\
\mathbf{P = F} / \mathbf{N} \mathbf{X} \mathbf{1 0 0} \%\end{array}$ \\
\hline 1 & $\begin{array}{l}\text { Kecendrungan menetap untuk } \\
\text { memperhatikan }\end{array}$ & 18 & $62 \%$ \\
\hline 2 & Rasa suka dan senang & 21 & $72 \%$ \\
\hline 3 & Antusias & 23 & $79 \%$ \\
\hline 4 & Rasa ingin tahu & 25 & $86 \%$ \\
\hline 5 & Kepuasan & 23 & $79 \%$ \\
\hline & Rata-rata & 22 & $75,6 \%$ \\
\hline
\end{tabular}

Berdasarkan hasil data lembar observasi pada pertemuan siklus I ini dapat disimpulkan bahwa terjadi peningkatan minat belajar siswa dari data pertemuan pra tindakan ke pertemuan 1 pada siklus I. Artinya pembelajaran Sosiologi menggunakan model kooperatif Teams Games Tournament dengan reward and punishment mampu membuat terjadinya peningkatan minat belajar siswa kelas XI IPS 2 SMAN 3 Padang. Pada tabel di atas dapat dilihat data yang menyatakan ada 1 indikator yang mencapai dalam kategori interval sangat baik, yaitu munculnya rasa ingin tahu siswa, sedangkan 4 indikator lainnya masih dalam kategori interval baik, yaitu Antusias, Kepuasan, Kecendrungan menetap untuk memperhatikan. Peneliti bersama kolaborator terus berusaha untuk melakukan refleksi bahwa peserta didik masih belum terbiasa dalam proses pembelajaran menggunakan bentuk permainan ini. Sehingga peneliti kembali menuntun siswa dalam pemahaman materi dengan pemberian reward kepada peserta didik yang berminat dan aktif dalam belajar dan memberikan punishment seperti hiburan dan memberikan peluang untuk siswa mengulang kembali materi pelajaran yang disampaikan guru. Guru meminta peserta didik untuk membaca sumber belajar yang diperoleh peserta didik sesuai dengan materi pelajaran yang akan dibahas pada pertemuan berikutnya. Perbadingan skor peningkatan minat belajar siswa dari pra tindakan ke pertemuan siklus I dapat dilihat dari tabel berikut:

Tabel 4. Perbandingan Peningkatan Minat Belajar Siswa Pada Pertemuan Pra Tindakan ke Siklus I

\begin{tabular}{lllll}
\hline No & Indikator Minat Belajar & $\begin{array}{c}\text { Persentase } \\
\text { Pra } \\
\text { Tindakan } \\
\mathbf{N = 3 5}\end{array}$ & $\begin{array}{c}\text { Persentase } \\
\text { siklus I } \\
\mathbf{N = 2 9}\end{array}$ & Peningkatan \\
& $46 \%$ & $62 \%$ & $16 \%$ \\
\hline 1 & Kecendrungan menetap untuk memperhatikan & $43 \%$ & $72 \%$ & $29 \%$ \\
\hline 2 & Rasa suka dan senang & $26 \%$ & $79 \%$ & $53 \%$ \\
\hline 3 & Antusias & $37 \%$ & $86 \%$ & $49 \%$ \\
\hline 4 & Rasa ingin tahu & $20 \%$ & $79 \%$ & $59 \%$ \\
\hline 5 & Kepuasan & $34,4 \%$ & $75,6 \%$ & $41,2 \%$ \\
\hline & Rata-rata & & & \\
\hline
\end{tabular}

\section{Siklus II}

Pada pertemuan siklus II ini peneliti dibantu kolaborator untuk melaksanakan penyebaran angket minat belajar untuk para siswa. Minat belajar siswa dilihat dari rata-rata masing-masing indikator minat belajar yang diamati. Pada pertemuan ini terdapat dua pertemuan, peneliti melihat adanya peningkatan dari pada pertemuan siklus I, karena dari 5 indikator minat belajar siswa 
tersebut meningkat ke interval sangat baik. Kenaikan di pertemuan siklus I ke pertemuan siklus II rata-rata minat belajar siswa naik sebesar 19\%, yang sebelumnya 75,6\% menjadi $94,6 \%$. Artinya pencapaian minat belajar siswa sudah dalam kategori sangat baik. Penjelasan tersebut dapat dilihat dari tabel berikut:

\section{Tabel 5. Pencapaian Minat Belajar Pada Siklus II}

\begin{tabular}{clcc}
\hline No & \multicolumn{1}{c}{ Indikator Minat Belajar } & $\begin{array}{c}\text { Jumlah } \\
\mathbf{N = 3 2}\end{array}$ & $\begin{array}{c}\text { Persentase } \\
\mathbf{P = F} / \mathbf{N ~ X ~ 1 0 0 ~ \% ~}\end{array}$ \\
\hline 1 & Kecendrungan menetap untuk memperhatikan & 31 & $97 \%$ \\
\hline 2 & Rasa suka dan senang & 31 & $97 \%$ \\
\hline 3 & Antusias & 29 & $91 \%$ \\
\hline 4 & Rasa Ingin Tahu & 31 & $97 \%$ \\
\hline 5 & Kepuasan & 29 & $91 \%$ \\
\hline \multicolumn{2}{r}{ Rata-rata } & $30,2 \%$ & $94,6 \%$ \\
\hline
\end{tabular}

Berdasarkan hasil data angket minat belajar pada pertemuan siklus II ini dapat disimpulkan bahwa terjadi peningkatan minat belajar siswa kelas XI IPS 2 dari pertemuan pra tindakan sebesar $34,4 \%$ ke pertemuan siklus I menjadi sebesar $75,6 \%$ dan setelah pertemuan siklus II menjadi $94,6 \%$. Artinya pembelajaran sosiologi menggunakan model kooperatif Teams Games Tournament dengan reward and punishment mampu meningkatkan minat belajar siswa kelas XI IPS 2 SMAN 3 Padang. Pada tabel di atas dapat dilihat data yang menyatakan ke 5 indikator minat tersebut sudah mencapai kategori interval sangat baik. Peningkatan tersebut dapat dilihat pada tabel perbandingan berikut ini:

Tabel 6. Perbandingan Peningkatan Minat Belajar Siswa Pada Pertemuan Pra Tindakan, Siklus II dan Siklus II

\begin{tabular}{llcccc}
\hline No & \multicolumn{1}{c}{$\begin{array}{c}\text { Indikator Minat } \\
\text { Belajar }\end{array}$} & $\begin{array}{c}\text { Persentase } \\
\text { Pra Tindakan } \\
\text { N=35 }\end{array}$ & $\begin{array}{c}\text { Persentase } \\
\text { Siklus I } \\
\mathbf{N = 2 9}\end{array}$ & $\begin{array}{c}\text { Persentase } \\
\text { Siklus II } \\
\mathbf{N}=32\end{array}$ & Peningkatan \\
\hline 1 & $\begin{array}{l}\text { Kecendrungan menetap } \\
\text { untuk memperhatikan }\end{array}$ & $46 \%$ & $62 \%$ & $97 \%$ & $51 \%$ \\
\hline 2 & Rasa suka dan senang & $43 \%$ & $72 \%$ & $97 \%$ & $54 \%$ \\
\hline 3 & Antusias & $26 \%$ & $79 \%$ & $91 \%$ & $65 \%$ \\
\hline 4 & Rasa Ingin Tahu & $37 \%$ & $86 \%$ & $97 \%$ & $60 \%$ \\
\hline 5 & Kepuasan & $20 \%$ & $79 \%$ & $91 \%$ & $71 \%$ \\
\hline & Rata-rata & $34,4 \%$ & $75,6 \%$ & $94,6 \%$ & $60,2 \%$ \\
\hline
\end{tabular}

Dari hasil tabel perbandingan peningkatan minat belajar siswa pada pertemuan siklus II dapat dijelaskan bahwa adanya kenaikan drastis dari minat belajar siswa kelas XI IPS 2 dilihat dari keberhasilan masing-masing indikator sudah mencapai target penelitian yaitu telah mencapai interval baik sekali. Dimana indikator yang paling tinggi ada 3 indikator yaitu indikator kecendrungan menetap untuk memperhatikan, indikator rasa suka dan senang dan indikator rasa ingin tahu yang persentasenya sebesar 97\%. Artinya pertemuan siklus II ini peneliti memutuskan untuk berhenti melakukan penelitian karena hasil sudah mencapai target penelitian. Salah satu upaya yang dapat dilaksanakan untuk menaikkan motivasi peserta didik dengan memberitahu hasil kemampuan siswa agar menumbuhkan kompetisi antar kelompok dan antar sesama siswa (Yulia Vermana \& Sylvia, 2019). 
Wahyu Ramadhani Putri, Junaidi Junaidi Upaya Meningkatkan Minat Belajar Siswa Melalui Penerapan Model Teams Games Tournament (TGT) dengan Reward and Punisment pada Pembelajaran Sosiologi di SMAN 3 Padang

\section{Kesimpulan}

Berdasarkan hasil data penelitian di atas dilihat dari hasil skor per indikator terjadi kenaikan. Persentase pada siklus I sebesar $75,6 \%$ dan pertemuan siklus II sebesar $94,6 \%$. Artinya skor ratarata sudah berada dikategori interval baik sekali. Dari pertemuan Siklus I dan Siklus II dapat dijelaskan bahwa proses belajar mengajar menggunakan model pembelajaran Teams Games Tournament dengan reward and punishment dapat meningkatkan minat belajar siswa kelas XI IPS 2 SMAN 3 Padang. Hal ini dapat dilihat dari hasil peningkatan rata-rata indikator minat belajar dari setiap pertemuan. Selanjutnya indikator yang kenaikan signifikan adalah indikator indikator kecendrungan menetap untuk memperhatikan, indikator rasa suka dan senang, dan indikator rasa ingin tahu dan indikator yang mengalami sedikit kenaikan yaitu indikator antusias dan indikator kepuasan. Dari 5 indikator minat belajar tersebut sudah mencapai tingkat pencapaian interval baik sekali.

\section{Daftar Pustaka}

Arikunto, S. (2008). Penelitian Tindakan Kelas. Jakarta: Bumi Aksara.

Hamalik, O. (2001). Proses Belajar Mengajar. Jakarta: PT Bumi Aksara

Istarani, I. (2012). 58 Model Pembelajaran Inovatif. Jakarta: Kencana

Jefri, J., \& Junaidi, J. (2019). Penerapan Model Talking Stick Untuk Meningkatkan Partisipasi Belajar Siswa Pada Pembelajaran Sosiologi Kelas X IPS 1 SMA Negeri 3 Bukittinggi 2019. Jurnal Perspektif, 2(3), 125-132. https://dx.doi.org/10.24036/ perspektif.v2i3.75

Majid, A. (2015). Strategi Pembelajaran. Bandung: PT Remaja Rosdakarya

Mayani, D. S., \& Junaidi, J. (2019). Penerapan Model TGT dengan Variasi LKPD Berbasis Kontekstual Untuk Meningkatkan Minat Belajar Sosiologi Siswa Kelas XI IPS 1 SMAN 1 2x11 Enam Lingkung Padang Pariaman. Jurnal Sikola: Jurnal Kajian Pendidikan dan Pembelajaran, 1(1), 37-44. https://doi.org/10.24036/sikola.v1i1.6

Muhaimin M.A. (1996). Strategi Belajar Mengajar. Surabaya: CV. Citra Media Karya Anak Bangsa

Nurlizawati, N. (2019). Penerapan Model Pembelajaran Tutor Teman Sebaya Di SMA Negeri 1 Pasaman. Socius: Journal of Sociology Research and Education, 6(1), 33-41. https://doi.org/10.24036/scs.v6i1.127

Robert E. Slavin. (2010). Cooperative Learning Teori, Riset dan Praktik. Bandung: Nusa Media.

Rosalina, L,\& Junaidi, J. (2020). Hubungan Minat Belajar dengan Hasil Belajar Siswa pada Pembelajaran Sosiologi Kelas XII IPS di SMA Negeri 5 Padang. Jurnal Sikola: Junal Kajian Pendidikan dan Pembelajaran, 1(3), 175-181. https://doi.org/10.24036/sikola.v1i3.24

Sagala, S. (2011). Konsep dan Makna Pembelajaran. Jakarta: Alfebeta

Slameto, S. (2010). Belajar dan Faktor-faktor yang Mempengaruhinya. Jakarta: Rineka Cipta

Suri, N. N. (2018). Penerapan Model Pembelajaran Kooperatif Tipe Teams Game Tournaments (TGT) untuk Meningkatkan Hasil Belajar Ilmu Pengetahuan Sosial. Jurnal Penelitian dan Pengembangan Pendidikan, 2(3), 256-257. https://doi.org/10.23887/jppp.v2i3.16283

Susanti, F. D., \& Junaidi, J. (2020). Studi Evaluasi Penerapan Strategi Pembelajaran Sosiologi di SMAN 2 Pariaman. Jurnal Sikola: Jurnal Kajian Pendidikan dan Pembelajaran, 1(3), 160-167. https://doi.org/10.24036/sikola.v1i1.6 
Sylvia, I., Anwar, S., \& Khairani, K. (2019). Pengembangan Instrumen Penilaian Autentik Berbasis Pendekatan Authentic Inquiry Learning Pada Mata Pelajaran Sosiologi di Sekolah Menengah Atas. Jurnal Socius: Journal of Sociology Research and Education, 6(2), 103-120. https://doi.org/10.24036/ scs.v6i2.162

Trianto, T. (2010). Model Pembelajaran Terpadu. Jakarta: Bumi Aksara.

Tyasning, D., Haryono, H., \& Nurhayati, N. (2012). Penerapan Model Pembelajaran Tgt (Teams Games Tournaments) Dilengkapi Lks Untuk Meningkatkan Aktivitas Dan Hasil Belajar Materi Minyak Bumi Pada Siswa Kelas X-4 SMA Batik 1 Surakarta Tahun Pelajaran 2011/ 2012. Jurnal Pendidikan Kimia Universitas Sebelas Maret, 1(1), 12-48.

Vermana, D.Y., \& Sylvia, I. (2019). Penerapan Model Group Investigation dalam Meningkatkan Kemampuan Kerjasama Siswa Kelas XI IPS di SMAN 6 Padang. Jurnal Sikola: Jurnal Kajian Pendidikan dan Pembelajaran, 1(1), 60-68. https://doi.org/ 10.24036/sikola.v1i1.10 